\title{
Phylogenetic Analysis of Frequent Recombinant Region in Micropeptin Biosynthetic Gene Cluster among the Genus Microcystis
}

\author{
Tomoyasu Nishizawa1*, Takamasa Miura1,2, Ayana Futamura1, Makoto Shirai1,3 \\ ${ }^{1}$ Department of Bioresource Science, Ibaraki University College of Agriculture, Ibaraki, Japan \\ ${ }^{2}$ Biological Resource Center, National Institute of Technology and Evaluation, Tokyo, Japan \\ ${ }^{3}$ College of Human and Cultural Sciences, Aikoku Gakuen University, Chiba, Japan \\ Email: *tomoyasu.nishizawa.agr@vc.ibaraki.ac.jp
}

Received 25 February 2016; accepted 24 April 2016; published 27 April 2016

Copyright (C) 2016 by authors and Scientific Research Publishing Inc.

This work is licensed under the Creative Commons Attribution International License (CC BY). http://creativecommons.org/licenses/by/4.0/

(c) (i) Open Access

\section{Abstract}

The gene cluster for the biosynthetic of a nonribosomal peptide, cyanopeptolins and micropeptin (MCN), was identified in Microcystis strains and halogenated MCN-producing Microcystis were found to possess the halogenase gene, $\operatorname{mcn} D$, between nonribosomal peptide synthetase genes, $m c n C$ and $m c n E$. A comparative sequence analysis of the $m c n$ gene cluster between halogenated and non-halogenated MCN-producing strains revealed mosaic sequence traces from $m c n D$ in the non-coding region between $m c n C$ and $m c n E$ in the latter strains. A phylogenetic analysis based on a 170-bp non-coding region including the $m c n D$ traces suggests that the recombination events occurred in a particular region of the Microcystis' mon gene. This study provides novel insight into the ecological patterning of widespread Microcystis species.

\section{Keywords}

Cyanobacteria, Microcystis, Micropeptin Biosynthetic Gene, Phylogenetic Analysis

Eutrophic and hypertrophic freshwater bodies worldwide are habitable environments for cyanobacteria [1]. As the unicellular cyanobacterium, Microcystis can be collected comparatively easily from lakes and ponds. It has been proposed as a model for studying the ecological patterning in free-living bacteria [2]. Ecological patterning

${ }^{*}$ Corresponding author.

How to cite this paper: Nishizawa, T., Miura, T., Futamura, A. and Shirai, M. (2016) Phylogenetic Analysis of Frequent Recombinant Region in Micropeptin Biosynthetic Gene Cluster among the Genus Microcystis. Advances in Microbiology, 6, 368-373. http://dx.doi.org/10.4236/aim.2016.65035 
may affect the concept of species through historical and/or contemporary environmental processes such as local selection, indicating that there are such ecologically distinct populations based on the Stable Ecotype Model [3] [4]. To investigate the concept of bacterial ecological species, the bacterial ribosomal RNA gene region is utilized [5]. However, it is difficult to differentiate distinct ecotypes of Microcystis according to the internal transcribed spacer sequence of 16S-23S rRNA [2].

Whole genome sequences of 12 genera of cyanobacteria have been decoded to date. The entire and draft genome sequences of Microcystis aeruginosa strains NIES-843 [6] and PCC 7806 [7], respectively, have been established. Notably, $11.8 \%$ of the genome of NIES-843 was occupied by mobile elements: insertion sequences and miniature inverted-repeat transposable elements [6]. This indicates that rearrangements of the genome, including the deletion and mutation of genes, have frequently occurred in Microcystis. Moreover, the genus is known to produce natural products via secondary metabolism. The gene for a cyclic heptapeptide microcystin (mcy) whose production involves nonribosomal peptide synthetase (NRPS) and polyketide synthase was identified in M. aeruginosa K-139 [8] [9]. A highly conserved mcy gene cluster was confirmed among the Microcystis [10]-[12]. Moreover, there were hotspots for the insertion and deletion of a fragment between a non-coding region of the ORF gene and the area adjacent to the cyclic heptapeptide microcystin and micropeptin gene (mcn) clusters among the genus [10] [11] [13].

We cloned and sequenced the genes mcnABCE, responsible for producing the heptadepsipeptide micropeptin belonging to the cyanopeptolin class, in M. aeruginosa K-139 and demonstrated that NRPS is involved in micropeptin production by means of $m c n$ gene-knockout [13]. In addition, according to a comparative analysis of the $m c n$ genes, we revealed the loss of a recombination event in relation to a halogenase gene, designated $m c n D$, within the $m c n$ gene cluster as well as proposed a clear evolutional history for the absence of a transcriptional region in $m c n D$. Therefore, we concluded that the $m c n D$ gene does not contribute to the production of non-halogenated MCNs [13]. Regarding NRPS-related halogenases, Cadel-Six et al. [14] proposed that the ancestral Microcystis had a mcn gene cluster containing a halogenase that was subsequently lost. Strain PCC 9812, which was isolated in Lake Mendota, United States, produces non-halogenated-MCN, but has an intact $m c n D$ [14]. On the other hand, non-halogenated-MCN producing Microcystis strains, K-139, NIES-102, NIES-103, and S-70, which were isolated in Lake Kasumigaura, Japan, and NIES-90, which was isolated from Lake Kawaguchi, Japan, were also identified (Table 1). Although we revealed that strain B-35, which strain possesses an intact $m c n D$, retained the $m c n A, m c n B, m c n C$, and $m c n E$ genes according to genomic Southern hybridization analysis [13], we have not identified the MCN compound in strain B-35 to date (T. Nishizawa and M. Shirai, unpublished data). To identify the transcription of the mon gene, a reverse transcribed-PCR analysis was carried out. For the reverse transcribed-PCR analysis, cells in a logarithmic growth phase were harvested, total RNA was isolated from M. aeruginosa B-35 and K-139 using hot phenol, and cDNA was prepared as described previously [8]. The reverse transcribed reaction was performed as described [15]. The primers sets for the $m c n A$ and $m c n D$ genes were F-mcnA-RT (5'-CGCCCAAAAATGTCACC-3') and R-mcnA (5'-AAGGGGAAATCTTGGGC-3') based on the $m c n A_{K-139}$ gene (accession number, AB481215) and F-hal-RT (5'-GGCGAATCAATCTTTACATCG-3') and R-hal-RT (5'-TCACTTACCAATTGCCTC-3') based on the $m c n D_{\mathrm{B}-35}$ gene (AB481216), respectively. PCR $(30 \mu \mathrm{L})$ was performed under the following condition; $3 \mathrm{~min}$ at $95^{\circ} \mathrm{C}$, then 25 cycles of $95^{\circ} \mathrm{C}(30 \mathrm{~s}), 58^{\circ} \mathrm{C}(30 \mathrm{~s})$, and $72^{\circ} \mathrm{C}(45 \mathrm{~s})$, and $72^{\circ} \mathrm{C}(2 \mathrm{~min})$. In this study, no transcription of $m c n A$ and $m c n D$ in strain B-35 was found though the transcription of a NRPS-related microcystin biosynthetic gene was observed (data not shown). From these results and our previous investigation of genomic Southern hybridization [13], it was suggested that the mcn gene cluster of strain B-35 may be pseudogenes. Therefore, strain B-35 is the first Microcystis strain which does not produce MCN although it has the $m c n$ gene cluster including the halogenase gene.

In this study, a detailed comparison of the mcn-related halogenase gene of Microcystis species was carried out. According to a comparative analysis of strains K-139 and B-35 based on $m c n C$ and $m c n E$, we propose that a loss of three DNA fragments occurred through recombination in a mosaic-like manner and then a nontranslated region containing a part of $m c n D$ arose in strain K-139 [13]. To examine the deletion of the intact $m c n D$ gene among the genus Microcystis, we selected 22 sequences of $m c n C-m c n E$ from the MCN-producing Microcystis strains (Table 1). The acceleration of the rate of nucleotide substitutions in the $m c n C-m c n E$ gene region among the genus Microcystis was calculated based on a phylogenetic analysis. Nucleotide sequences of the $m c n C-E$ region were aligned using Clustal W [27]. The bootstrap test was performed on 500 replicates. A neighbor-joining (NJ) tree was constructed [28] and evolutionary distances were computed using the Tajima's test in MEGA 4 
Table 1. Summary of cyanopeptolin-producing Microcystis and Anabaena strains.

\begin{tabular}{|c|c|c|c|c|}
\hline Strain & Geographic origin & Peptide & $\begin{array}{l}\text { Sequence of } m c n C-m c n E \text {, } \\
\text { accession number }\end{array}$ & Reference \\
\hline \multicolumn{5}{|l|}{ M. aeruginosa } \\
\hline B-35 & Japan $^{\mathrm{a}}$ & no & AB481216 & This study \\
\hline B-47 & Japan $^{\mathrm{a}}$ & n.d. ${ }^{\mathrm{c}}$ & AB481217 & [13] \\
\hline K-139 & Japan $^{\mathrm{a}}$ & micropeptin K139 & AB481215 & [16] \\
\hline NIES-89 & Japan $^{\text {b }}$ & n.d. & AB481218 & [14] \\
\hline NIES-90 & Japan $^{\text {b }}$ & micropeptin 90 & AB481219 & [17] \\
\hline NIES-298 & Japan $^{\mathrm{a}}$ & n.d. & AM773670 & [14] \\
\hline PCC 7005 & United States & cyanopeptolin $954^{\mathrm{d}}$ & AM773675 & [18] \\
\hline PCC 7806 & Netherlands & $\begin{array}{c}\text { cyanopeptolin A } \\
\text { cyanopeptolin B } \\
\text { cyanopeptolin 963A }\end{array}$ & AM773668 & $\begin{array}{l}{[19]} \\
{[19]} \\
{[20]}\end{array}$ \\
\hline PCC 7813 & Scotland & aeruginopeptin 228A & AM773665 & [21] \\
\hline PCC 7941 & Canada & $\begin{array}{l}\text { cyanopeptolin } 1040 \mathrm{~A}^{\mathrm{d}} \\
\text { cyanopeptolin } 1006 \mathrm{~A}\end{array}$ & AM773676 & $\begin{array}{l}{[14]} \\
{[22]}\end{array}$ \\
\hline PCC 9603 & Sweden & cyanopeptolin $989^{d}$ & AM773677 & [14] \\
\hline PCC 9622 & France & cyanopeptolin S & AM773669 & [23] \\
\hline PCC 9807 & South Africa & $\begin{array}{l}\text { cyanopeptolin } 1020 \\
\text { cyanopeptolin } 1005\end{array}$ & AM773673 & $\begin{array}{l}{[22]} \\
{[14]}\end{array}$ \\
\hline PCC 9808 & Australia & $\begin{array}{l}\text { cyanopeptolin 1040B } \\
\text { cyanopeptolin 1040C }\end{array}$ & AM773674 & $\begin{array}{l}{[14]} \\
{[14]}\end{array}$ \\
\hline PCC 9809 & United States & $\begin{array}{l}\text { aeruginopeptin 228-A } \\
\text { aeruginopeptin 228-B }\end{array}$ & AM773671 & $\begin{array}{l}{[21]} \\
{[21]}\end{array}$ \\
\hline PCC 9812 & United States & cyanopeptolin 1020 & AM773679 & [22] \\
\hline PCC 9905 & United States & cyanopeptolin $954^{\mathrm{d}}$ & AM773678 & [18] \\
\hline PCC 10025 & France & cyanopeptolin & AM773672 & [14] \\
\hline \multicolumn{5}{|l|}{ M. viridis } \\
\hline NIES-102 & Japan $^{\mathrm{a}}$ & cyanopeptolin & AB481220 & [14] \\
\hline NIES-103 & Japan $^{\mathrm{a}}$ & micropeptin NIES103 & AB481221 & [24] \\
\hline S-70 & Japan $^{\mathrm{a}}$ & $\begin{array}{l}\text { micropeptin S70-A } \\
\text { micropeptin S70-B }\end{array}$ & AB481222 & $\begin{array}{l}{[16]} \\
{[16]}\end{array}$ \\
\hline \multicolumn{5}{|l|}{ M. wesenbergii } \\
\hline $\begin{array}{l}\text { NIVA-CYA } \\
172 / 5\end{array}$ & Denmark & cyanopeptolin $984^{\mathrm{d}}$ & DQ075244 & [25] \\
\hline \multicolumn{5}{|l|}{ Anabaena sp. } \\
\hline Strain 90 & Finland & 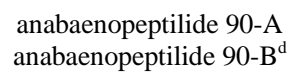 & AJ269505 & $\begin{array}{l}{[26]} \\
{[26]}\end{array}$ \\
\hline
\end{tabular}

${ }^{\mathrm{a}}$ Isolated in Lake Kasumigaura. ${ }^{\mathrm{b}}$ Isolated in Lake Kawaguchi. ${ }^{\mathrm{c}}$ n.d. not determined. ${ }^{\mathrm{d}}$ Chlorinated cyanopeptolin.

program [29]. When a phylogenetic analysis of the 92-bp sequence (downstream non-coding region) using 21 strains excluding strain NIVA-CYA 172/5 [14] was conducted with a non-coding region between downstream of $a p d C$ involved in halogenation of the depsipeptide anabaenopeptilide and upstream of $a d p D$ in the heterocyst Anabaena sp. strain 90 [26] as an outgroup, these 92-bp sequences formed one group (data not shown). Then, a 
phylogenetic analysis was performed based on the non-coding region of 170-bp, which is mosaic sequence traces, between $m c n C$ and $m c n E$ except for the 92-bp fragment in strain K-139 [13]. In this phylogenetic analysis, the apdC gene was used as an outgroup. The phylogenetic relationship shown in Figure 1(a) clearly divided into two clades, mosaic sequence traces (clade I) and the intact $m c n D$ gene (clade II). Interestingly, strain K-139 placed outside of clade I (Figure 1(a)). Except for strain K-139, the relative rate of substitution was examined at a number of sites (170-bp) using the shortest branch of strain PCC 9622 in clade I and the longest branch of strain B-35, which has a 54-bp insertion sequence upstream of $m c n D$ [13], in clade II. The number of nucleotide substitutions per site was 0.112:0.018 (6-folds, $\chi^{2}=11.64, P<0.001$ ). When strain K-139 was used instead of strain PCC 9622, the number was 0.064:0.035 $\left(\chi^{2}=1.47, P=0.23\right)$. Otherwise, excluding the outgroup of $a d p C$, we estimate the average evolutionary divergence of the 170-bp and 92-bp sequence pairs to be 0.097 and 0.045 , respectively. These investigations indicate an acceleration of the rate of nucleotide substitutions in clade I. Moreover, the rate increased in the truncated $m c n D$ gene region rather than the non-coding region (92-bp) between $m c n D$ and $m c n E$.

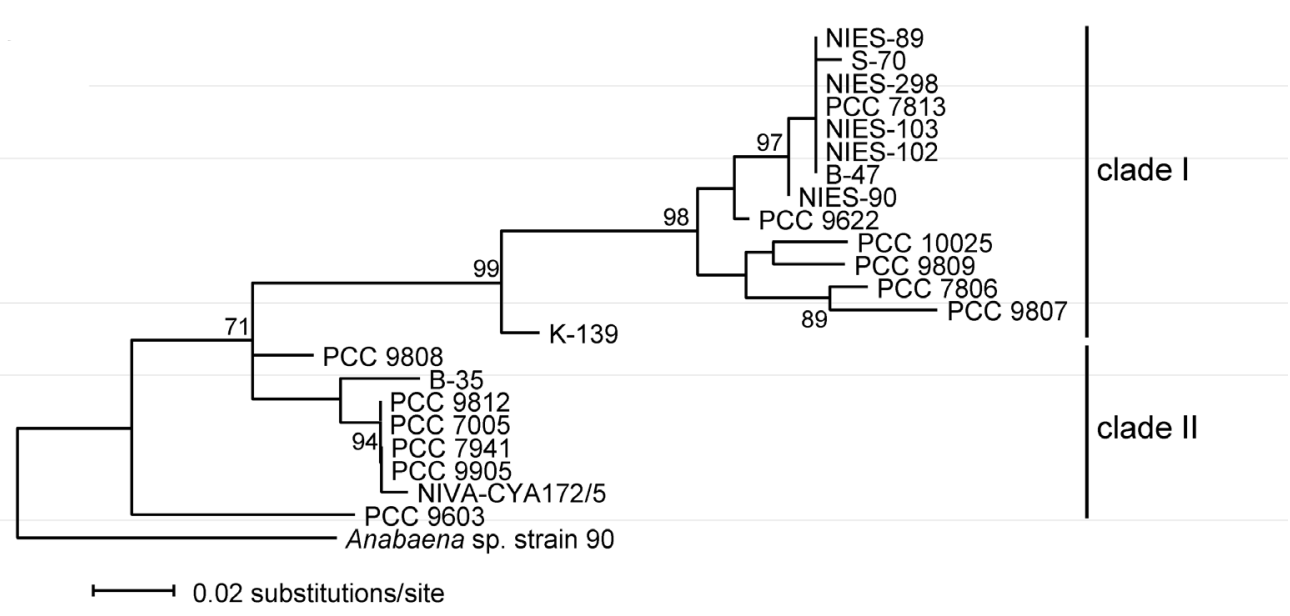

(a)

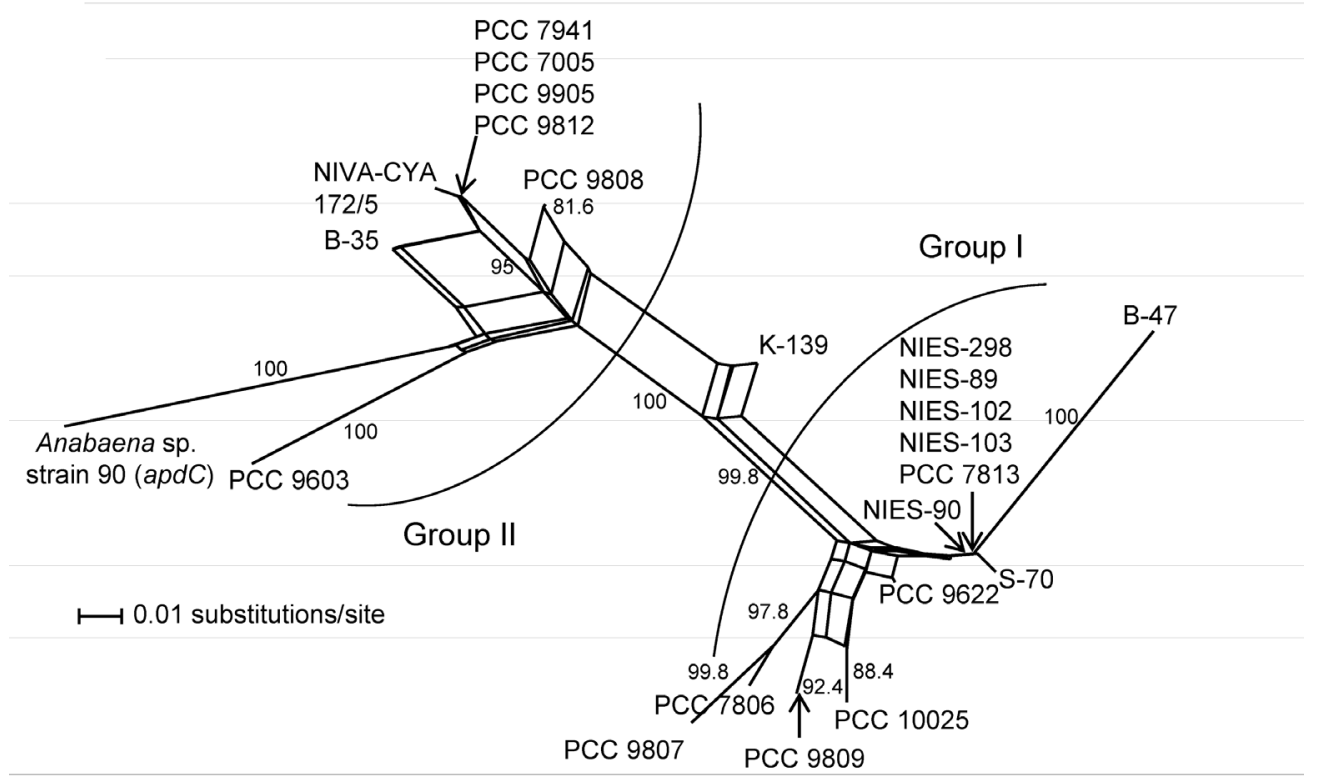

(b)

Figure 1. Phylogenetic relationship determined using the neighbor-joining method (a) and a splits decomposition analysis (b) of the mcnC-E region of Microcystis strains. Only bootstrap values exceeding $70 \%$ are shown. There were a total of 170 positions in the final dataset. 
To determine the genetic relationship of strain K-139 to both clades, a splits decomposition analysis was carried out using the 170-bp sequence. Recombination was investigated by a split decomposition analysis using SplitsTree Version 4 [30] with default settings (uncorrected P method) and 500 bootstrap replicates. As shown in Figure 1(b), the 170-bp non-coding region of strain K-139 placed in between the two groups. Phylogenetic analyses revealed that the truncated $m c n D$ gene of strain K-139 is a unique sequence, indicating the strain to have a unique non-halogenated-MCN genotype. In addition, lower divergence of the 170-bp non-coding region was found within the non-halogenated-MCN genotypes isolated in Lake Kasumigaura and Lake Kawaguchi, Japan except strain B-47 in group I (Figure 1(b)). Our results indicate that the region between $m c n C$ and $m c n E$ is the evolutionary hotspot among non-halogenated MCN-producing Microcystis.

Conclusively, the diversified sequences of the intact and truncated $m c n D$ gene may imply that halogenated MCN- and non-halogenated MCN-producing Microcystis occur individually. In the present study, the existence of a truncated $m c n D$-possessing Microcystis peculiar to Lake Kasumigaura was showed and it is assumed that truncated $m c n D$ such as strain K-139 is purged. Our results show new insight into the ecological patterning of widespread Microcystis species. Further isolation of mcy and mcn-possessing Microcystis strains is needed to elucidate the ecological species of Microcystis that have adapted genetically to local ecosystems.

\section{Acknowledgements}

We thank Dr. Takashi Kitano (Ibaraki University College of Engineering) for critical comments about evolutionary divergence and valuable discussions. We thank Dr. Akito Nishizawa of the laboratory of M.S. for technical assistance.

\section{References}

[1] Mur, L.R., Skulberg, O.M. and Utkilen, H. (1999) Cyanobacateria in the Environment, p. 25-54. In: Chorus, I. and Bartram, J., Eds., Toxic Cyanobacteria in Water, WHO, E and FN Spon, London.

[2] van Gremberghe, I., Leliaert, F., Mergeay, J., Vanormelingen, P., van der Gucht, K., Debeer, A.-E., Lacerot, G., de Meester, L. and Vyverman, W. (2011) Lack of Phylogeographic Structure in the Freshwater Cyanobacterium Microcystis aeruginosa Suggests Global Dispersal. PLoS One, 6, e19561. http://dx.doi.org/10.1371/journal.pone.0019561

[3] Cohan, F.M. (2006) Toward a Conceptual and Operation Union of Bacterial Systematics, Ecology, and Evolution. Philosophical Transactions of the Royal Society B, 361, 1985-1996. http://dx.doi.org/10.1098/rstb.2006.1918

[4] Ward, D.M., Cohan, F.M., Bhaya, D., Heidelberg, J.F., Kühl, M. and Grossman, A. (2008) Genomics, Environmental Genomics and the Issue of Microbial Species. Heredity, 100, 207-219. http://dx.doi.org/10.1038/sj.hdy.6801011

[5] Fraser, C., Alm, E.J., Polz, M.F., Spratt, B.G. and Hanage, W.P. (2009) The Bacterial Species Challenge: Making Sense of Genetic and Ecological Diversity. Science, 323, 741-746. http://dx.doi.org/10.1126/science.1159388

[6] Kaneko, T., Nakajima, N., Okamoto, S., Suzuki, I., Tanabe, Y., Tamaoki, M., Nakamura, Y., Kasai, F., Watanabe, A., Kawashima, K., Kishida, Y., Ono, A., Shimizu, Y., Takahashi, C., Minami, C., Fujishiro, T., Kohara, M., Katoh, M., Nakazaki, N., Nakayama, S., Yamada, M., Tabata, S. and Watanabe, M.M. (2007) Complete Genomic Structure of the Bloom-Forming Toxic Cyanobacterium Microcystis aeruginosa NIES-843. DNA Research, 14, 247-256. http://dx.doi.org/10.1093/dnares/dsm026

[7] Frangeul, L., Quillardet, P., Castets, A.M., Humbert, J.F., Matthijs, H.C., Cortez, D., Tolonen, A., Zhang, C.C., Gribaldo, S., Kehr, J.C., Zilliges, Y., Ziemert, N., Becker, S., Talla, E., Latifi, A., Billault, A., Lepelletier, A., Dittmann, E., Bouchier, C. and Tandeau de Marsac, N. (2008) Highly Plastic Genome of Microcystis aeruginosa PCC 7806, a Ubiqui- tous Toxic Freshwater Cyanobacterium. BMC Genomics, 9, 274. http://dx.doi.org/10.1186/1471-2164-9-274

[8] Nishizawa, T., Asayama, M., Fujii, K., Harada, K.-I. and Shirai, M. (1999) Genetic Analysis of the Peptide Synthetase Genes for a Cyclic Heptapeptide Microcystin in Microcystis spp. Journal of Biochemistry, 126, 520-529. http://dx.doi.org/10.1093/oxfordjournals.jbchem.a022481

[9] Nishizawa, T., Ueda, A., Asayama, M., Fujii, K., Harada, K.-I., Ochi, K. and Shirai, M. (2000) Polyketide Synthase Gene Coupled to the Peptide Synthetase Module Involved in the Biosynthesis of the Cyclic Heptapeptide Microcystin. Journal of Biochemistry, 127, 779-789. http://dx.doi.org/10.1093/oxfordjournals.jbchem.a022670

[10] Nishizawa, T., Nishizawa, A., Asayama, M., Harada, K.-I. and Shirai, M.(2007) Diversity within the Microcystin Biosynthetic Gene Clusters among the Genus Microcystis. Microbes and Environments, 22, 380-390. http://dx.doi.org/10.1264/jsme2.22.380

[11] Noguchi, T., Shinohara, A., Nishizawa, A., Asayama, M., Nakano, T., Hasegawa, M., Harada, K.-I., Nishizawa, T. and Shirai, M. (2009) Genetic Analysis of the Microcystin Biosynthesis Gene Cluster in Microcystis Strains from Four Bo- 
dies of Eutrophic Water in Japan. Journal of General and Applied Microbiology, 55, 111-123. http://dx.doi.org/10.2323/jgam.55.111

[12] Tooming-Klunderud, A., Mikalsen, B., Kristensen, T. and Jakobsen, K.S. (2008) The Mosaic Structure of the $m c y A B C$ Operon in Microcystis. Microbiology, 154, 1886-1899. http://dx.doi.org/10.1099/mic.0.2007/015875-0

[13] Nishizawa, T., Ueda, A., Nakano, T., Nishizawa, A., Miura, T., Asayama, M., Fujii, K., Harada, K.-I. and Shirai, M. (2011) Characterization of the Locus of Genes Encoding Enzymes Producing Heptadepsipeptide Micropeptin in the Unicellular Cyanobacterium Microcystis. Journal of Biochemistry, 149, 475-485. http://dx.doi.org/10.1093/jb/mvq150

[14] Cadel-Six, S., Dauga, C., Castets, A.M., Rippka, R., Bouchier, C., Tandeau de Marsac, N. and Welker, M. (2008) Halogenase Genes in Nonribosomal Peptide Synthetase Gene Clusters of Microcystis (Cyanobacteria): Sporadic Distribution and Evolution. Molecular Biology and Evolution, 25, 2031-2041. http://dx.doi.org/10.1093/molbev/msn150

[15] Matsui, M., Yoshimura, T., Wakabayashi, Y., Imamura, S., Tanaka, K., Takahashi, H., Asayama, M. and Shrai, M. (2007) Interference Expression at Levels of the Transcript and Protein among Group 1, 2, and 3 Sigma Factor Genes in a Cyanobacterium. Microbes and Environments, 22, 32-43. http://dx.doi.org/10.1264/jsme2.22.32

[16] Harada, K.-I., Nakano, T., Fujii, K. and Shirai, M. (2004) Comprehensive Analysis System Using Liquid Chromatography-Mass Spectrometry for the Biosynthetic Study of Peptides Produced by Cyanobacteria. Journal of Chromatography A, 1033, 107-113. http://dx.doi.org/10.1016/j.chroma.2004.01.006

[17] Ishida, K., Matsuda, H., Murakami, M. and Yamaguchi, K. (1996) The Absolute Sterochemistry of Micropeptin 90. Tetrahedron Letters, 37, 9225-9226. http://dx.doi.org/10.1016/S0040-4039(96)02189-2

[18] von Elert, E., Oberer, L., Merkel, P., Huhn, T. and Blom, J.F. (2005) Cyanopeptolin 954, a Chlorine-Containing Chymotrypsin Inhibitor of Microcystis aeruginosa NIVA Cya 43. Journal of Natural Products, 68, 1324-1327. http://dx.doi.org/10.1021/np050079r

[19] Martin, C., Oberer, L., Ino, T., König, W.A., Busch, M. and Weckesser, J. (1993) Cyanopeptolins, New Depsipeptides from the Cyanobacterium Microcystis sp. PCC 7806. Journal of Antibiotics, 46, 1550-1556.

[20] Bister, B., Keller, S., Baumann, H.I., Nicholson, G., Weist, S., Jung, G., Süssmuth, R.D. and Jüttner, F. (2004) Cyanopeptolin 963A, a Chymotrypsin Inhibitor of Microcystis PCC 7806. Journal of Natural Products, 67, 1755-1757. http://dx.doi.org/10.1021/np049828f

[21] Harada, K.-I., Mayumi, T., Shimada, T., Suzuki, M., Kondo, F. and Watanabe, M.F. (1993) Occurrence of Our Depsipeptides, Aeruginopeptins, Together with Microcystins from Toxic Cyanobacteria. Tetrahedron Letters, 34, 6091-6094. http://dx.doi.org/10.1016/S0040-4039(00)61736-7

[22] Welker, M., Brunke, M., Preussel, K., Lippert, I. and von Döhren, H. (2004) Diversity and Distribution of Microcystis (Cyanobacteria) Oligopeptide Chemotypes from Natural Communities Studied by Single-Colony Mass Spectrometry. Microbiology, 150, 1785-1796. http://dx.doi.org/10.1099/mic.0.26947-0

[23] Weckesser, J., Martin, C. and Jakobi, C. (1996) Cyanopeptolins, Depsipeptides from Cyanobacteria. Systematic and Applied Microbiology, 19, 133-138. http://dx.doi.org/10.1016/S0723-2020(96)80038-5

[24] Murakami, M., Kodani, S., Ishida, K., Matsuda, H. and Yamaguchi, K. (1997) Micropeptin 103, a Chymotrypsin Inhibitor from the Cyanobacterium Microcystis viridis (NIES-103). Tetrahedron Letters, 38, 3035-3038. http://dx.doi.org/10.1016/S0040-4039(97)00528-5

[25] Tooming-Klunderud, A., Rohrlack, T., Shalchian-Tabrizi, K., Kristensen, T. and Jakobsen, K.S. (2007) Structural Analysis of a Non-Ribosomal Halogenated Cyclic Peptide and Its Putative Operon form Microcystis: Implications for Evolution of Cyanopeptolins. Microbiology, 153, 1382-1393. http://dx.doi.org/10.1099/mic.0.2006/001123-0

[26] Rouhiainen, L., Vakkilainen, T., Siemer, S., Buikema, W., Haselkorn, R. and Sivonen, K. (2000) Genes Encoding Synthetases of Cyclic Depsipeptides, Anabaenopeptilides, in Anabaena Strain 90. Molecular Microbiology, 37, 156167. http://dx.doi.org/10.1046/j.1365-2958.2000.01982.x

[27] Thompson, J.D., Higgins, D.G. and Gibson, T.J. (1994) CLUSTAL W: Improving the Sensitivity of Progressive Multiple Sequence Alignment through Sequence Weighting, Position Specific Gap Penalties and Weight Matrix Choice. Nucleic Acids Research, 22, 4673-4680. http://dx.doi.org/10.1093/nar/22.22.4673

[28] Tamura, K., Nei, M. and Kumar, S. (2004) Prospects for Inferring Very Large Phylogenies by Using the NeighborJoining Method. Proceedings of the National Academy of Sciences of the United States of America, 101, 11030-11035. http://dx.doi.org/10.1073/pnas.0404206101

[29] Tamura, K., Dudley, J., Nei, M. and Kumar, S. (2007) MEGA4: Molecular Evolutionary Genetics Analysis (MEGA) Software Version 4.0. Molecular Biology and Evolution, 24, 1596-1599. http://dx.doi.org/10.1093/molbev/msm092

[30] Huson, D.H. and Bryant, D. (2006) Application of Phylogenetic Networks in Evolutionary Studies. Molecular Biology and Evolution, 23, 254-267. http://dx.doi.org/10.1093/molbev/msj030 